\title{
FLAVIVIRUSES AT THE TERRITORY OF SERBIA - PRESENT SITUATION AND CHALLENGES
}

Tamaš Petrovićn ${ }^{11^{*}}$, Milanko Šekler ${ }^{2}$, Dušan Petrićs ${ }^{3}$ Dejan Vidanović ${ }^{2}$, Aleksandar Potkonjak ${ }^{4}$, Ivana Hrnjaković Cvjetkovićs, ${ }^{5,6}$, Sara Savić ${ }^{1}$, Zoran Debeljak $^{2}$, Gospava Lazić ${ }^{1}$, Aleksandra Ignjatović Ćupina ${ }^{3}$,

Diana Lupulović ${ }^{1}$, Milena Samojlović ${ }^{1}$, Aleksandar Jurišić ${ }^{7}$, Aleksandra

Petrović ${ }^{7}$, Ivana Ivanović ${ }^{7}$, Vesna Milošević ${ }^{5,6}$, Sava Lazić ${ }^{1}$

${ }^{1}$ Scientific Veterinary Institute "Novi Sad"

${ }^{2}$ Specialized Veterinary Institute "Kraljevo"

${ }^{3}$ University of Novi Sad, Faculty of Agriculture, Laboratory for Medical and Veterinary Entomology

${ }^{4}$ University of Novi Sad, Faculty of Agriculture, Department of Veterinary Medicine

${ }^{5}$ University of Novi Sad, Faculty of Medicine, Department of Microbiology, with Parasitology and Immunology

${ }^{6}$ Institute of Public Health of Vojvodina, Virology Centre, Novi Sad

${ }^{7}$ University of Novi Sad, Faculty of Agriculture, Department of Plant and Environmental Protection

\section{Abstract}

The aim of this study is to summarize the data on the occurrence, presence and prevalence of some zoonotic flaviviruses, which have been actively circulating in the territory of the Republic of Serbia during past decade. The genus Flavivirus, family Flaviviridae,encompasses vector-transmitted viruses with zoonotic potential. The genus is comprised of more than 70 viruses transmitted to humans by mosquitoes and ticks. Some of those are associated only with human diseases (such as yellow fever and dengue fever), whereas others can cause diseases in both humans and animals. Animals are major reservoirs and primary hosts for the latter group. The virus transmission to other animal species or humans occurs via diverse vectors - mostly mosquitoes and ticks. A range of these virus species is widely distributed worldwide, especially in tropical and sub-tropical climatic zones. Some representatives of these species have only recently been identified at the territory of Republic of Serbia. This paper gives an evidence on the presence and

${ }^{1 *}$ Corresponding author tomy@niv.ns.ac.rs 
distribution of West-Nile virus, tick-borne encephalitis (TBE) virus and Usutu virus that were conducted within the study in Serbia. The research pointed out the presence of recently detected West-Nile virus and Usutu virus as well as the current circulation of tick-borne encephalitis virus, for which only limited serological evidence on the presence of virus-specific antibodies in humans was available so far. In the aspect of public health, the full understanding of the importance of identification and prevalence of different flaviviruses still require further comprehensive entomologicalacarological, seroepidemiological, clinical and virological research.

Key words: flaviviruses, West-Nile virus, tick-borne encephalitis virus, Usutu virus, Serbia

\title{
FLAVIVIRUSI NA PODRUČJU SRBIJE - TRENUTNO STANJE I IZAZOVI
}

\author{
Tamaš Petrović ${ }^{1}$, Milanko Šekler ${ }^{2}$, Dušan Petrić 3 , Dejan Vidanović \\ Aleksandar Potkonjak ${ }^{4}$, Ivana Hrnjaković Cvjetković ${ }^{5,6}$, Sara Savić ${ }^{1}$, \\ Zoran Debeljak², Gospava Lazić', Aleksandra Ignjatović Ćupina ${ }^{3}$, \\ Diana Lupulović ${ }^{1}$, Milena Samojlović ${ }^{1}$, Aleksandar Juriši ić ${ }^{7}$, Aleksandra \\ Petrović $^{7}$, Ivana Ivanović 7 , Vesna Milošević ${ }^{5,6}$, Sava Lazić ${ }^{1}$ \\ ${ }^{1}$ Naučni institut za veterinarstvo "Novi Sad" \\ ${ }^{2}$ Veterinarski specijalistički institut "Kraljevo" \\ ${ }^{3}$ Univerzitet u Novom Sadu, Poljoprivredni fakultet, Laboratorija \\ za medicinsku i veterinarsku entomologiju \\ ${ }^{4}$ Univerzitet u Novom Sadu, Poljoprivredni fakultet, \\ Departman za veterinarsku medicinu \\ ${ }^{5}$ Univerzitet u Novom Sadu, Medicinski fakultet, Katedra za \\ mikrobiologiju sa parazitologijom i imunologijom \\ ${ }^{6}$ Institut za javno zdravlje Vojvodine, Centar za virusologiju, Novi Sad \\ ${ }^{7}$ Univerzitet u Novom Sadu, Poljoprivredni fakultet, \\ Departman za fitomedicinu i zaštitu životne sredine
}

\section{Kratak sadržaj}

Cilj ovoga rada je da sumarno prikaže podatke o pojavi, prisustvu i raširenosti nekih zoonotskih flavivirusa čija cirkulacija je utvrđena na području Republike Srbije tokom poslednjih desetak godina. U rod Flavivirus, familije Flaviviridae, spadaju vektorski prenosivi virusi zoonotskog 
potencijala. Rod obuhvata više od 70 vrsta virusa koji se preko komaraca i krpelja prenose na ljude. Neki od ovih virusa izazivaju oboljenja samo ljudi (kao što su žuta groznica i Denga), dok drugi izazivaju oboljenja životinja i ljudi. Rezervoari i prirodni domaćini za ove drugo navedene viruse su pre svega životinje a virusi se putem različitih vektora, najčešće komaraca i krpelja mogu preneti i na druge vrste životinja, kao i na ljude. Veći broj vrsta ovih virusa je široko rasprostranjen u svetu, posebno u tropskim i suptropskim klimatskim pojasevima. Pojedini predstavnici ovoga roda su utvrđeni na području Republike Srbije tek u skorašnjem periodu. U radu su prikazani podaci istraživanja koja su sprovedena na području Republike Srbije, a odnose se na utvrđivanje prisustva i raširenosti virusa Zapadnog Nila, virusa krpeljskog encefalitisa i Usutu virusa. Pomenuta istraživanja su ukazala, kako na prisustvo skorije detektovanih virusa Zapadnog Nila i Usutu virusa, tako i na trenutnu cirkulaciju virusa krpeljskog encefalitisa za koji su ranije postojali ograničeni serološki podaci o prisustvu antitela kod ljudi. Za razumevanje istinskog značaja nalaza i prevalencije različitih flavivirusa za javno zdravlje u Republici Srbiji, neophodno je sprovesti detaljnija entomološko-akarološka, sero-epidemiološka, klinička i virusološka istraživanja.

Ključne reči: flavivirusi, virus Zapadnog Nila, virus krpeljskog encefalitisa, Usutu virus, Srbija

\section{PRESENCE AND PREVALENCE OF WEST NILE VIRUS (WNV)}

West Nile virus (WNV) is a neurovirulent mosquito-borne flavivirus with zoonotic potential. The virus is maintained in nature in an enzootic transmission cycle between avian hosts and mosquito vectors, mainly from the genus Culex but also some other mosquito species. The virus occasionally infects other vertebrates, including humans and horses, in which it may cause sporadic disease outbreaks that could result in fatal outcomes (Martin-Acebes et al., 2012). WNV was first isolated in 1937 (Smithburn et al., 1940) from samples originating from highly febrile woman in Uganda (West Nile district). This is how the infection got its name West Nile Fever (WNF). Nowadays, it is considered second, after Dengue virus, most widespread flavivirus in the world. WNV is endemic in the regions of Africa, Asia, Europe, Middle East, Australia and Americas (Komar et al., 2003; Hrnjaković-Cvjetković et al., 2009; Calistri et al., 2010; Weissenböck et al., 2010 and Papa et al., 2011). In Europe, mainly in the countries of Mediterranean Basin, only lineage 1 strains circulated until 
2004, when lineage 2 strain was (for the first time in Europe) isolated in goshawks in Hungary. Ever since, the lineage 2 WNV strains have been identified in a range of wild bird species and mosquitoes with established vector capacity as well as in humans in Hungary, Austria, Russia, Italy, Greece and more recently in Serbia (Bakonyi et al., 2006; Valiakos et al., 2011; Savini et 1., 2012; Papa et al., 2011; Erdély et al., 2007; Platonov et al.,2008; Wodak et al., 2011; Bagnarelli et al., 2011; Petrović et al., 2013).

In the aspect of human and animal health, wild birds are particularly important due to migration across national and intercontinental borders they contribute to a long-range virus spread (Linke et al., 2007). Many bird species, though not all that are susceptible to infection, produce levels of viremia that are sufficient for transmitting the virus to mosquitoes (Komar et al., 2003). Humans and mammals, especially horses, are incidental "dead-end" hosts and play limited roles in the natural cycle because viremia after infection is generally too low to allow further virus transmission to the mosquitoes at the moment of bite (Hrnjaković-Cvjetković et al., 2009; Valiakos et al., 2010). However, in both humans and horses, severe neuroinvasive disease with even fatal outcomes can occur. Infections in humans predominantly take a subclinical course (80-90\% of cases). Some infected individuals (up to 20\%) can manifest mild clinical symptoms resembling influenza associated with sudden fever, headache, sour throat and pain in the back, muscles and joints, fatigue, mild transient rash and lymphadenopathy. However, in only a small subset (one per 150 cases) of mostly elderly patients and patients with comorbidities the infection can progress to severe neuroinvasive disease with encephalitis or meningoencephalitis, occasionally with fatal outcomes (Blitvich, 2008; Hrnjaković-Cvjetković et al., 2009). Similarly to humans, WNV infection in horses is usually not accompanied with apparent clinical symptoms. Nevertheless, neurological symptoms can occur in some $10 \%$ of cases with a mortality rate that can reach even 50\% (Blitvich, 2008; Calistri et al., 2010). The virus has been present in Europe for many years, but dramatic increase of the incidence and severity of epidemic outbreaks with neurological complications in birds, humans and horses has been recorded in central and southern Europe in recent years, which is considered an emerging veterinary and public health problem (Martin-Acebes and Saiz, 2012; Petrović et al., 2013).Apart from some historical data, first reports on the presence of West Nile virus (WNV) in Serbia became available upon testing of horse blood sera for the presence of WNV-specific antibodies in the region of Vojvodina Province. The first study was performed using blood sera collected during 2009 and 2010. The presence of WNV-specific antibodies was detected applying immunoenzyme as- 
say (ELISA) and subsequent plaque reduction neutralization test (PRNT) in $12 \%(46 / 349)$ of examined samples (Lupulović et al., 2011). Surprisingly, high percentage of seropositive horses initiated further research, thus, serological testing has continued during following three years. WNV-antibody testing applying ELISA conducted on horse blood sera in 2011 revealed 28.6\% (72/252) seropositive animals, whereas $49.2 \%$ (64/130) and 46.9\% (45/96) seropositive horse blood sera were identified in tests conducted during 2012 and 2013, respectively (Medić et al., 2014; Petrović et al., 2014a; Petrović et al., 2015). Pronounced increase in the prevalence of seropositive horses strongly suggested an intensive circulation of WNV in the environment. In spite of high prevalence, clinical manifestations of the disease have not been reported, i.e., confirmed in the laboratory. Circulation of WNV in the nature has been confirmed by ELISA and PRNT in 5/92 (5.4\%) blood sera of wild birds positive to anti-WNV antibodies as well as by virus detection in tissue samples of $8 / 82(9.8 \%)$ dead wild birds using real-time RT-PCR. The analysis included samples of 134 wild birds (belonging to 46 species) and was conducted in the territory of Vojvodina Province of Serbia during the first half of 2012 (Petrović et al., 2013). Besides the aforementioned, the presence of WNV genome was detected by real-time $R T$-PCR in 6\% (3/50) and 9.15\% (28/306) of the examined mosquito's samples pools collected during 2010 and 2013, respectively (Petrić et al., 2012; Petrović et al., 2015). Moreover, positive reaction to the presence of WNV antibodies in ELISA test was observed in 5.04\% (17/337) of examined human samples collected from Vojvodina Province in 2010 (Petrić et al., 2012). Since 2012, when first WNV epidemic associated with apparent clinical picture in humans was reported, the human outbreaks have been recorded every year (ECDC, 2012; Popović et al., 2013). National monitoring programme for WNV funded by the Veterinary Directorate and conducted by scientific and specialized veterinary institutes and field veterinary service in close collaboration with entomologists and ornithologists was launched in 2014. The program proved successful in view of identifying presence and circulation of WNV among sentinel animals (domestic poultry and horses in 2014 and only in horses in other years), and in wild birds and mosquitoes before infection outbreaks in humans in every particular season. The program, with minor modification, has continued during 2015, 2017 and 2018 (Petrović et al., 2014b; Petrović et al., 2018). The main objectives of this program include early detection of WNV in certain region and timely reporting to relevant health service institutions and local authorities responsible for establishing of appropriate mosquito control, sharing the information to the community and taking preventive measures for human and animal health protection. The monitoring programme relies on direct and in- 
direct detection (surveillance) of WNV presence in the environment. Surveillance by indirect detection of WNV includes serological testing of sentinel horses and poultry (poultry was included in surveillance only during 2014). The testing is performed periodically during most intense mosquito activity (June-September). The number of tested sentinel animals is defined at the level of each district according to the assessment of the risk of exposure to WNV. Direct monitoring of the presence of WNV involves periodical examination of pooled mosquito samples collected at two-week intervals in the period of their most intense activity (June-September) and testing of wild bird samples (tissues of dead birds and swabs taken from live wild birds of susceptible species) for the presence of WNV. The number of samples is also defined at the level of each district according to estimated risk of WNV infection (Petrović et al., 2018). Some results of the WNV monitoring program conducted during 2014 and 2015 are presented in figures (Figures 1-4).

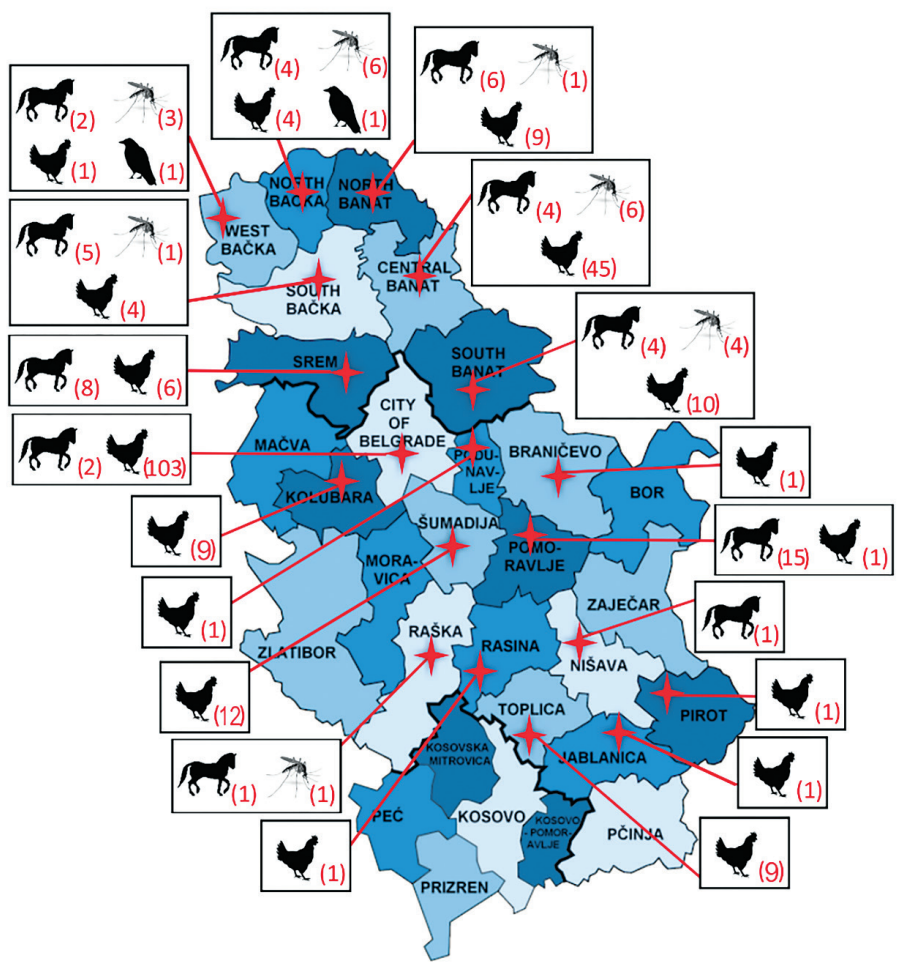

Figure 1. Results of WNV monitoring programme in the Republic of Serbia during 2014 - (n) number of positive findings in mosquitoes and wild birds, WNV specific antibodies in sentinel horses and poultry per Districts level 


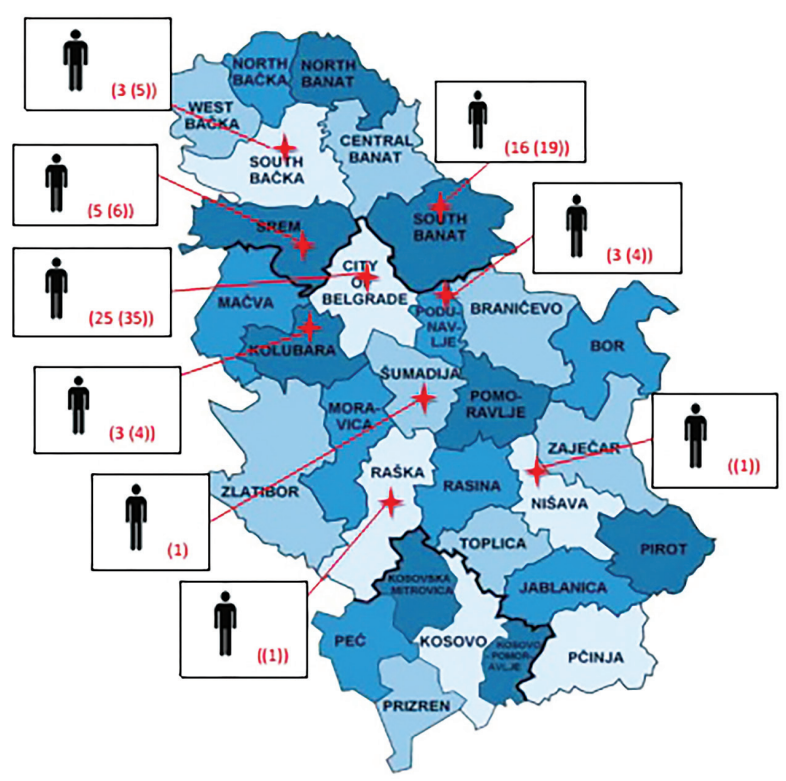

Figure 2. Recorded cases of West Nile Disease in humans in 2014 - (n) reported clinical cases confirmed in the laboratory; ((n)) reported clinical cases not confirmed in the laboratory

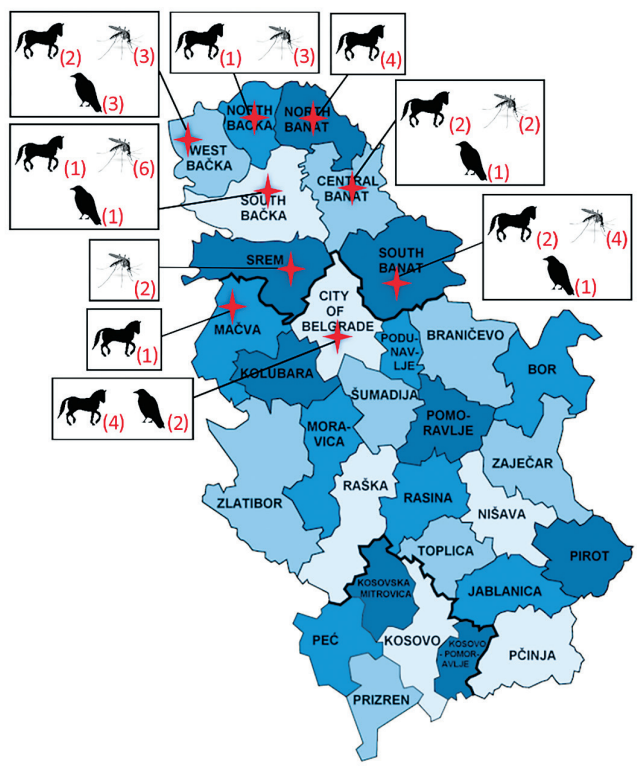

Figure 3. Results of WNV monitoring programme in the Republic of Serbia during 2015 - (n) number of positive findings of WNV and virus specific antibodies in mosquitoes, wild birds and sentinel horses per Districts level 


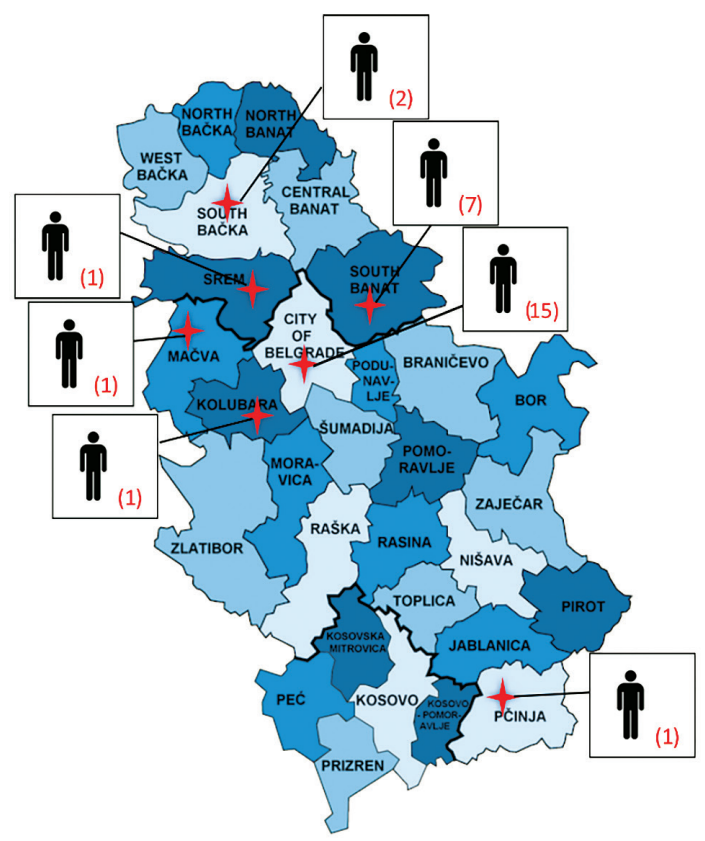

Figure 4. Recorded cases of West Nile Disease in humans in 2015 - (n) reported clinical cases confirmed in the laboratory

\section{PRESENCE AND DISTRIBUTION OF TICK-BORNE ENCEPHALITIS VIRUS (TBEV)}

Tick-borne Encephalitis (TBE) is viral infectious disease most commonly distributed in the central and eastern regions of Europe, and Asia. The infection is transmitted predominantly via infected ticks. The disease occurs in endemic areas, naturally active foci in the presence of virus reservoirs (small rodents). There is no direct animal-to-animal or person-to-person virus transmission. However, animal-to-human transmission is possible via products of animal origin, predominantly by consuming non-pasteurized milk and dairy products, mainly from goats and cattle (Balogh et al., 2010; Hudopisk et al., 2013). Most often the virus is transmitted to humans by the bite of ticks of the genus Ixodes. The ticks can get infected at all stages of their life cycle and remain disease vectors throughout their entire life. Virus replication in tick's body and transovarial transmission to following generation enable the maintenance of TBEV among vector population. Majority of clinical infections have been re- 
corded in dogs (Pfeffer and Dobler, 2011) and horses (Klaus et al., 2013), while asymptomatic infections are common in domestic ruminants, which represent an important epidemiological problem in view of virus transmission to humans (Balogh et al., 2010; Hudopisk et al., 2013; Caini et al., 2012).

In the territory of former Yugoslavia, the first findings, of virus isolation from the blood of infected person in Slovenia date back to 1953 (VesenjakZmijanac et al., 1955). From this period onwards, the presence of TBEV has been reported in the western part of ex-Yugoslavia, predominantly in Republic of Slovenia as an endemic region. At that time, virus presence was not established in the territory of Serbia (Petrović et al., 2017). First reports on the presence of TBEV in Serbia are based upon serological examinations by hemagglutination-inhibition (HI) assay, which encompassed 1,726 blood serum samples of healthy humans collected in the territory of Republic of Serbia from 1962 to 1969. The presence of TBEV-specific antibodies was established in $1.1 \%-52.6 \%$ of tested individuals (1.1\% from the region of Srem; $2 \%$ from the region of Central Serbia; 3.6\% from the region of East Serbia; 7.3\% from the territory of Belgrade; $8.4 \%$ from the region of Banat; $19.4 \%$ from the region of West Serbia; $37.8 \%$ from the region of Kosovo and 52.6\% from the region of Sandžak). The virus was isolated in 1972 from a tick originating from the region of Sandžak (Bordjoški et al., 1972; Petrović et al., 2017). Some more recent serological tests for the presence of TBEV applying ELISA method revealed the presence of antibodies against TBEV in 7.9\% (8/101) of healthy individuals in the region of South Bačka, whereas no positive findings $(0 / 80)$ were reported in Nišava district (Hrnjaković-Cvjetković et al., 2014).

Several decades after the first isolation, the presence of tick-borne encephalitis virus (TBEV) was confirmed by real-time RT-PCR, conventional RT-PCR and genome sequencing in ticks of the genus Ixodes ricinus collected during 2014 and 2015. Examination of 50 ticks from two localities in Fruška Gora mountain and 15 localities in the region of Belgrade revealed the presence of TBEV in 2\% (1/50) and 6.6\% (30/450) examined ticks at two out of 17 localities (Andrevlje/Fruška Gora and Manastirska šuma, Rakovica/Belgrade region), respectively. One of the detected TBEV isolates was sequenced and phylogenetically typed as European (Western) TBEV subtype (Figure 5). In addition, low prevalence of TBEV antibodies was established by ELISA in $0.37 \%(1 / 267)$ of the examined blood sera collected in the same period from patients at the Clinic for Infectious Diseases of the Clinical Centre of Vojvodina (Potkonjak et al., 2017).

Some recent data on the presence of TBEV in animals came from serological research that included 200 animal blood sera collected during 2014 
and 2015. ELISA analysis of the aforementioned sera revealed the presence of TBEV-specific antibodies in $17.5 \%$ (7/40) of dogs, $5 \%(1 / 20)$ horses, $12.5 \%$ $(5 / 40)$ wild boars, $2.5 \%(1 / 40)$ cattle and $2.5 \%(1 / 40)$ of roe deer. The presence of TBEV-specific antibodies was not established in any $(0 / 20)$ of the examined goat blood sera (Potkonjak et al., 2017). Apart from the abovementioned research, TBEV was first established in animals in Serbia in 2017. Virus was confirmed by RT-PCR in blood samples of sick 2 year old horse and mare originating from the same household in the region managed by Specialized Veterinary Institute „Požarevac“. Sick animals manifested neurological symptoms accompanied by epileptic seizures with lethal outcome (Živojinović et al., 2017).

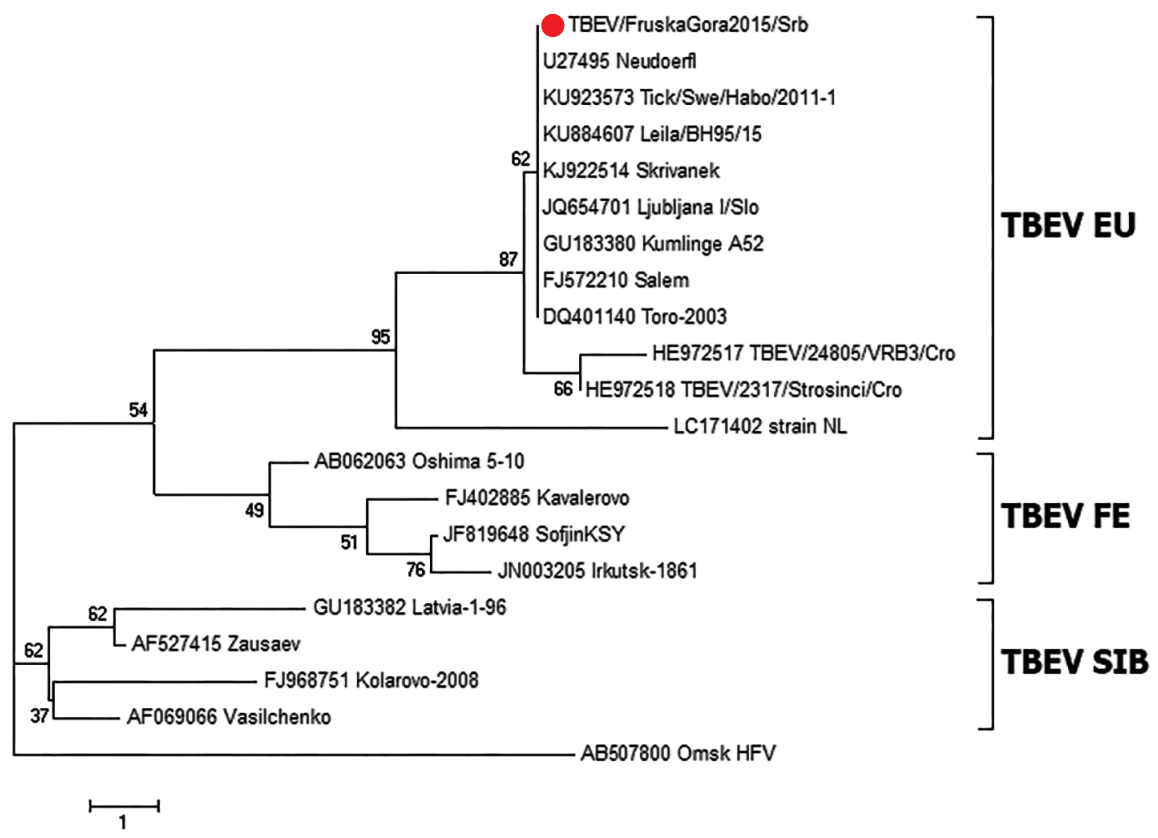

Figure 5. Molecular typing of TBEV isolate detected in tick species Ixodes ricinus in the region of Fruška Gora Mountain (marked with red circle) in relation to virus strains available from NCBI GenBank. TBEV EU = strains of European or Western TBEV subtype; TBEV FE = strains of Far eastern TBEV subtype; TBEV SIB = strains of Siberian TBEV subtype (Figure from Potkonjak et al., 2016).

\section{PRESENCE AND DISTRIBUTION OF USUTU VIRUS (USUV)}

Usutu virus (USUV) was first isolated in 1959 from Culex neaevii mosquitoes in the region along the river Usutu (after which the virus is named) 
in Swaziland (since recently, Eswatini - South Africa region) (Williams et al., 1964). First human isolates were detected in 1981 and 2004 in ill persons from the regions of Central African Republic and Burkina Faso, respectively (Nikolay et al., 2011). The presence of USUV in Europe was first established when the first recognized outbreak of USUV occurred among blackbirds Turdus merula in Austria in 2001 (Weissenböck et al., 2002), and later also in other European countries. The recently published research confirmed the presence of the virus in archived tissue samples from Italian wild birds found dead in 1996 strongly suggesting that USUV was circulating in the region of Europe even before 2001 (Weissenböck et al., 2013). Natural cycle of USUV is similar to that of the WNV. Diverse species of wild birds are the reservoirs (amplification host) and natural hosts of the virus, while mosquitoes, mainly of the Culex genus, serve as major vectors, although USUV was found in other mosquito species (Hrnjaković-Cvjetković et al., 2017; Vilibić-Čavlek et al., 2015; Saiz and Blázquez, 2017). In the infected birds, clinical symptoms of the disease can vary from asymptomatic infection to massive deaths associated with multisystem infection. Lethal USUV infections were reported in Passeriformes birds) with most susceptible blackbird species (Turdus merula), house sparrow (Passer domesticus) and magpie (Pica pica) as well as owls from the order of Strigiformes. In highly susceptible bird species, USUV manifests a broad tissue tropism and tends to replicate in diverse tissues (central nervous system, muscle tissue, fibroblasts, epithelial cells of the intestines and respiratory tract, lymphoid tissues etc.) thus causing dysfunction of multiple organs and lethal outcome. The disease commonly takes acute or per acute course, frequently associated with poor immune response (Vilibić-Čavlek et al., 2015; Saiz and Blázquez, 2017).

Experimental infections proved that gees and chicken can get infected with USUV, but they do not develop clinical symptoms of the disease and shed the virus only intermittently. Once infected with USUV, humans and horses show low level of viraemia, thus becoming accidental final hosts that could not serve as a virus host for further virus spreading ("dead-end" hosts for virus transmission). Clinical manifestations among humans and horses are rare and closely similar to those associated with WNV. The majority of infections are asymptomatic. Neurological manifestations as encephalitis and meningoencephalitis can occur only in limited number of cases (Hrnjaković-Cvjetković et al., 2017; Vilibić-Čavlek et al., 2015; Saiz and Blázquez, 2017). According to data published so far, USUV has been identified in birds and mosquitoes in the territory of Austria, Hungary, Spain, Italy and Belgium. Besides, USUV infection is serologically confirmed in wild birds in England, Czech Republic, 
Germany, Italy, Poland, Spain and Switzerland (Hrnjaković-Cvjetković et al., 2017; Vilibić-Čavlek et al., 2015; Saiz and Blázquez, 2017). Seroconversion in horses for the first time was reported in Italy in 2009 (Barbić et al., 2013). First detection of USUV antibodies in wild birds in Serbia dates back from 2012, during the testing for the presence of West Nile virus (Petrović et al., 2013). For the first time, USUV-specific antibodies were detected in horses in Serbia and Croatia in 2009 and 2011, respectively (Lupulović et al., 2011; Barbić et al., 2013). These findings undoubtedly indicated the presence and circulation of the virus in both Serbia and Croatia, which initiated further research predominantly focused on the presence of specific antibodies in humans. During 2015, the testing of blood sera from persons potentially exposed to mosquitoborne arbovirus infections was performed using ELISA test. The examination included 88 blood sera of people from the region of South Bačka, Serbia. The presence of USUV antibodies was confirmed in 5\% (4/88) of tested individuals (Hrnjaković-Cvjetković et al., 2014). In Croatia, the presence of USUV-specific antibodies was confirmed in 2012 in one person from Vukovar area, and first clinical cases of human USUV infection were identified in 2013 (3 patients with neuroinvasive disease - meningitis and meningoencephalitis - from the region of Zagreb) (Vilibić-Čavlek et al., 2014; 2015). The first case of human USUV infection in Europe was reported in Italy (Pecorari, 2009).

The presence of USUTU virus for the first time was detected in Serbia using real-time RT-PCR and classic RT-PCR in $0.9 \%(2 / 216)$ of pooled mosquito samples collected in the territory of South Bačka district during 2015 (42), as well as in 2.75\% (3/109) of analysed polled samples of mosquitoes of the species Culex pipiens collected in the territory of Vojvodina Province during 2017 (Petrović et al., 2018b). Two of USUTU viruses detected in 2017 were sequenced and identified as lineage 2 of the European - Western USUV subtype (Figure 6). This research has confirmed the previous serological findings in animals and humans from the territory of Serbia. 


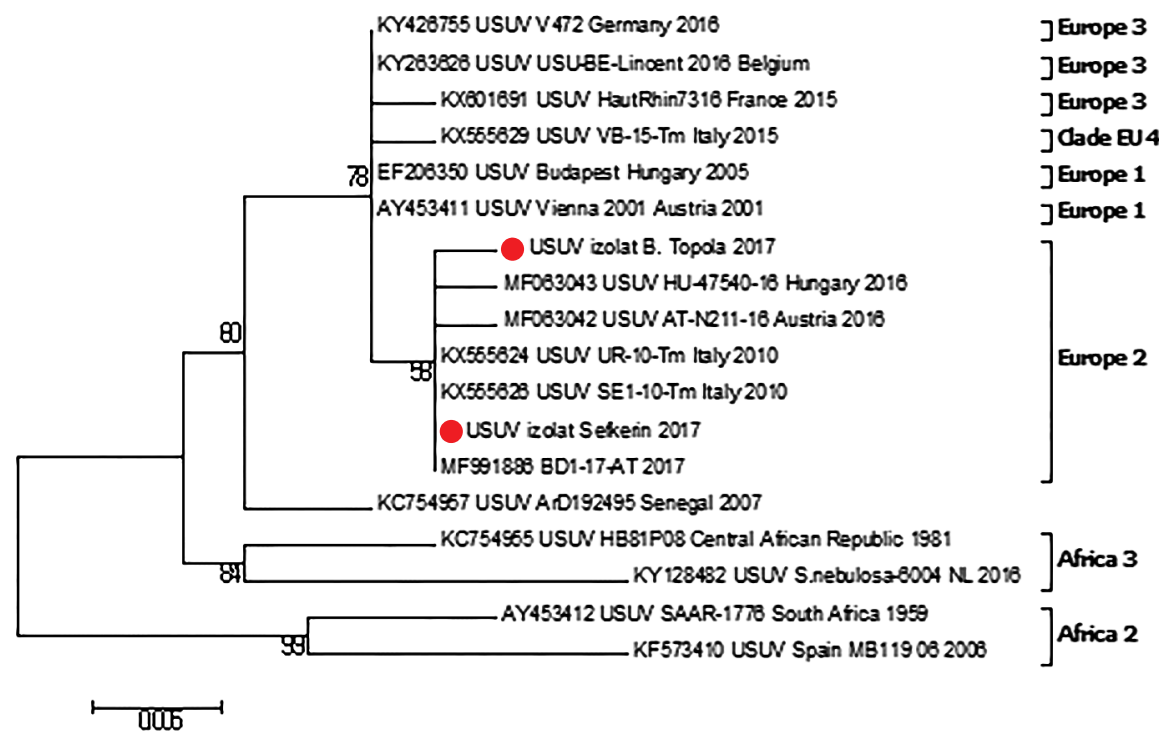

Figure 6. Molecular typing of 2 USUV detected in mosquitoes in the region of Bačka Topola and Sefkerin during 2017 (marked with red circle) in relation to referent virus strains and isolates available from the gene banks (NCBI GenBank). Legend on the right side presents different USUV lineages.

\section{INSTEAD OF A CONCLUSION}

The objective of this article was to summarize the research in the field of epidemiology and diagnostics of flavivirus infections conducted in the region of Serbia during past decade and to offer an overview of current epidemiological and epizootic situation as well as of measures of the surveillance of WNV currently in force in Republic of Serbia. Research results obtained through annual surveillance programmes have already offered answers to some questions on the presence and distribution of some flavivirus infections such as WNV. However, they launched other emerging issues related to the incidence and prevalence of TBEV and USUV. Also, there are issues of interaction between these three viral infections in terms of the problem of differential diagnosis due to similar clinical manifestations, as well as the hazards to human and animal health. Understanding of public health importance of the presence and prevalence of different flaviviruses requires further comprehensive seroepidemiological, clinical and virological research. Apparent and pronounced climatic changes entail intensive spread of specific vectors towards North; 
thus, occurrence of certain flavivirus infections so far unknown in the region of Serbia should be expected. In that respect, further research should involve permanent monitoring of vector distribution and their infection status in view of the presence of pathogenic agents of human and animal diseases, as well as the presence of pathogens among the population of natural hosts and reservoirs. Upon that point, establishing of a comprehensive surveillance program is compulsory to obtain all necessary information and to get the answers related to risk analysis and adequate preventive and control measures.

\section{AKNOWLEDGMENTS}

This work was produced within the framework of Project TR31084 funded by the Ministry of Education, Science and Technological Development of Republic of Serbia.

\section{REFERENCES:}

1. Bagnarelli P., Marinelli K., Trotta D., Monachetti A., Tavio M., Del Gobbo R., Capobianchi M.R., Menzo S., Nicoletti L., Magurano F., Varaldo P.E. Human case of autochthonous West Nile virus lineage 2 infection in Italy. Eurosurveillance, 16, 43, pii=20002, 2011.

2. Bakonyi T., Ivanics E., Erdelyi K., Ursu K., Ferenczi E., Weissenbock H., Nowotny N. Lineage 1 and 2 strains of encephalitic West Nile virus, central Europe. Emerging Infectious Diseases, 12(4), 618-623, 2006.

3. Balogh Z., Ferenczi E., Szeles K., Stefanoff P., Gut W., Szomor K.N., et al. Tick-borne encephalitis outbreak in Hungary due to consumption of raw goat milk. Journal of Virological Methods. 163(2), 481-5, 2010.

4. Barbic L., Vilibic-Cavlek T., Listes E., Stevanović V., Gjenero-Margan I., Ljubin-Sternak S., Pem-Novosel I., Listes I., Mlinarić-Galinović G., Di Gennaro A., Savini G. Demonstration of Usutu virus antibodies in horses, Croatia. Vector - Borne and Zoonotic Diseases. 13, 772-774, 2013.

5. Blitvich B.J. Transmission dynamics and changing epidemiology of West Nile virus. Animal Health Research Review, 9(1), 71-86, 2008.

6. Bordjoski M., Gligic A., Boskovic R.. Arbovirus infections in Serbia. Vojnosanitetski pregled, 29(4), 173-5, 1972.

7. Caini S., Szomor K., Ferenczi E. et al. Tick-borne encephalitis transmitted by unpasteurised cow milk in western Hungary, September to October 2011. Eurosurveillance, 17(12), pii=20128, 2012.

8. Calistri P., Giovannini A., Hubalek Z., Ionescu A., Monaco F., Savini G., 
Lelli R. Epidemiology of West Nile in Europe and the Mediterranean basin. The Open Virology Journal, No 4, 29-37, 2010.

9. European Centre for Disease Prevention and Control (ECDC). Reported cases of West Nile fever for the EU and neighbouring countries. Situations update 30. November 2012. [Pristupljeno $16 \mathrm{dec} 2012$ ].

10. Erdélyi K., Ursu K., Ferenczi E., Szeeredi L., Ratz F., Skare J., Bakonyi T. Clinical and pathological features of linage 2 West Nile virus: Infections in birds of prey in Hungary. Vector - Borne and Zoonotic Diseases, 7 (2), 181-188, , 2007

11. Hrnjaković-Cvjetković I., Cvjetković D., Petrić D., Milošević V., Jerant-Patić V., Zgomba M. Savremena saznanja o infekciji virusom Zapadnog Nila. Medicinski Pregled, 62 (5/6), 231-235, 2009.

12. Hrnjakovic Cvjetkovic I., Patic A., Nikolic N., Radovanov J., Kovačevic G., Galovic J.A., et al. Seroprevalence of West Nile Virus and Tick-borne encephalitis virus in South Backa District and Nisava District. Abstract book of 48th Days of Preventive Medicine, Nis, Serbia, , P. 35, 35-48, 2014.

13. Hrnjaković Cvjetković I., Petrovic T., Petric D., Milosevic U., Radovanov J., Kovacevic G., Jovanovic Galović A., Patić A., Nikolic N., Cvjetković D., Stefan Mikić S., Milosević V. Usutu virus: an emerging flavivirus in Europe. Arhiv veterinarske medicine, 10(1), 25-35, 2017.

14. Hudopisk N., Korva M., Janet E., Simetinger M., Grgič Vitek M., Gubnšek J., et al. Tick-borne encephalitis associated with consumption of raw goat milk, Slovenia, 2012. Emerging Infectious Diseases, 19(5), 806-808, 2013.

15. Klaus C., Horugel U., Hoffmann B., Beer M. Tick-borne encephalitis virus (TBEV) infection in horses: Clinical and laboratory findings and epidemiological investigations. Veterinary Microbiology, 163, 368-372, 2013.

16. Komar N., Langevin S., Hinten S., Nemeth N., Edwards E., Hettler D., Davis B., Bowen R., Bunning M. Experimental infection of North American birds with the New York 1999 Strain of West Nile virus. Emerging Infectious Diseases, 9 (3), 311-322, 2003.

17. Linke S., Niedrig M., Kaiser A., Ellerbrok H., Muller K., Muller T., Conraths F.J., Muhle R.U., Schmidt D., Koppen U., Bairlein F., Berthold P., Pauli G. Serologic evidence of West Nile virus infections in wild birds captured in Germany. American Journal of Tropical Medicine and Hygiene, 77, 358364, 2007.

18. Lupulović D., Acebes M., Lazić S., Alonso-Padilla J., Bláquez A.B., Escribano-Romero E., Petrović T., Saiz J.C. First Serological Evidence of West Nile Virus Activity in Horses in Serbia. Vector - Borne and Zoonotic Diseases, 11(9), 1303-1305, 2011. 
19. Martin-Acebes M.A., Saiz J.C. West Nile virus: a re-emerging pathogen revisited. World Journal of Virology, 1(2), 51-70, 2012.

20. Medić S., van den Hoven R., Petrović T., Lupulović D., Nowotny N. Serological evidence of West Nile virus infection in the horse population of northern Serbia. Journal of Infection in Developing Countries 8(7), 914-918, doi:10.3855/jidc.3885, 2014.

21. Pecorari M., Longo G., Gennari W., Grottola A., Sabbatini A., Tagliazucchi S., et al.: First human case of Usutu virus neuroinvasive infection, Italy, August-September 2009. Eurosurveillance, 14, 50, 19446, 2009.

22. Nikolay B., Diallo M., Boye C.S.B., Sall A.A. Usutu virus in Africa. Vector Borne and Zoonotic Diseases, 11, 1417-1423, 2011.

23. Papa A., Bakonyi T., Xanthopoulou K., Vazquez A., Tenorio A., Nowotny N. Genetic characterization of West Nile virus lineage 2, Greece, 2010. Emerging Infectious Diseases, 17, 920-922, 2011.

24. Petrić D., Hrnjaković Cvjetković I., Radovanov J., Cvjetković D., Jerant Patić V., Milošević V., Kovačević G., Zgomba M., Ignjatović Ćupina A., Konjević A., Marinković, D., Paz Sánchez-Seco M. West nile virus surveillance in humans and mosquitoes and detection of cell fusing agent virus in Vojvodina province (Serbia). HealthMED, 6, 2, 462-468, 2012.

25. Petrović T., Blazquez A., Lupulović D., Lazić G., Escribano-Romero E., Fabijan D., Kapetanov M., Lazić S., Saiz J.C. Monitoring West Nile virus (WNV) infection in wild birds in Serbia during 2012: first isolation and characterisation of WNV strains from Serbia. Eurosurveillance, 18, 44, 1-8, 2013.

26. Petrović T., Lazić S., Lupulović D., Lazić G., Bugarski D., Vidanović D., Stefan-Mikić S., Milošević V., Hrnjaković-Cvetković I., Petrić D. Serological study on WNV presence in horses in Vojvodina after the human outbreak in Serbia in 2012. Archives of Biological Sciences, 66 (2), 473-481, DOI:10.2298/ABS1402473P, 2014a.

27. Petrović T., Šekler M., Petrić D., Lazić S., Lupulović D., Lazić G., Debeljak Z., Bugarski D., Plavšić B.: West Nile virus surveillance program in Serbia $=$ Program nadzora prisustva virusa zapadnog Nila u Srbiji. Arhiv veterinarske medicine, 7, 2, 29-45, 2014b.

28. Petrović T., Lupulović D., Petrić D., Vasić A., Hrnjaković-Cvjetković I., Milošević V., Vidanović D., Šekler M., Lazić S., Đuričić B., Plavšić B., Saiz J.: Groznica zapadnog Nila - značajna vektorska virusna infekcija u Srbiji: aktuelna situacija $=$ WNV infection - an emergent vector borne viral infection in Serbia: Current situation. Veterinarski glasnik, 69, 1-2, 111-126, 2015.

29. Petrović, V.; Ristanović, E.; Potkonjak, A.; TBE in Serbia. In: Dobler, G.; Erber, W.; Schmitt H.J. Eds: TBE-The Book. Global Health Press 2017. https:// 
id-ea.org/tbe/tbe-countries-serbia/.

30. Petrović T., Šekler M., Petrić D., Lazić S., Debeljak Z., Vidanović D., Ignjatović Ćupina A., Lazić G., Lupulović D., Kolarević M., Plavšić B.. Methodology and results of integrated WNV surveillance programmes in Serbia. PLoS ONE, 13(4), e0195439, 2018.

31. Petrović T., Lazić G., Ignjatović Ćupina A., Lazić S., Lupulović D., Samojlović M., Hrnjaković Cvjetković I., Milošević V., Petrić D. Presence of Usutu virus in mosquitoes in Vojvodina Province in 2017. Book of Abstracts, XX Simpozijum epizootiologa i epidemiologa, 8.-20. april 2018., Vrnjačka Banja, 48-49, 2018b

32. Pfeffer M., Dobler G. Tick-borne encephalitis virus in dogs-is this an issue? Parasit Vectors, 4, 59, 2011.

33. Platonov A.E., Fedorova M.V., Karan L.S., Shopenskaya T.A., Platonova O.V., Zhuravlev V.I. Epidemiology of West Nile infection in Volgograd, Russia, in relation to climate change and mosquito (Diptera: Culicidae) bionomics. Parasitology Research, 103, Suppl 1, 45-53, 2008.

34. Popović N., Milošević B., Urošević A., Poluga J., Lavadinović L., Nedelijković J., Jevtović D., Dulović O. Outbreak of West Nile virus infection among humans in Serbia, August to October 2012. Eurosurveillance, 18(43), pii=20613, 2013.

35. Potkonjak A., Petrović T., Ristanović E., Lalić I., Vračar V., Savić S., Turkulov V., Čanak G., Milošević V., Vidanović D. et al. Molecular Detection and Serological Evidence of Tick-Borne Encephalitis Virus in Serbia. Vector - Borne and Zoonotic Diseases, 17, 12, 813-820, doi:10.1089/vbz.2017.2167, 2017.

36. Saiz J-C., Blázquez A-B. Usutu virus: current knowledge and future perspectives. Virus Adaptation and Treatment, 9, 2017.

37. Savini G., Monaco F., Terregino C. et al. Usutu virus in Italy: An emergence or a silent infection. Veterinary Microbiology, 151, 264-274, 2011.

38. Savini G., Capelli G., Monaco F., Polci A., Russo F., Di Gennaro A., Marini V., Teodori L., Montarsi F., Pinoni C., Pisciella M., Terregino C., Marangon S., Capua I., Lelli R. Evidence of West Nile virus lineage 2 circulation in Northern Italy. Veterinary Microbiology, 158, 3-4, 267-273, 2012.

39. Smithburn K.C., Hughes T.P., Burke A.W., Paul J.H. A neurotropic virus isolated from the blood of a native of Uganda. American Journal of Tropical Medicine and Hygiene, 20, 471-492, 1940.

40. Valiakos G., Touloudi A., Iacovakis C., Athanasiou L., Birtsas P., Spyrou V., Billinis C. Molecular detection and phylogenetic analysis of West Nile virus lineage 2 in sedentary wild birds (Eurasian magpie), Greece, 2010. Eurosurveillance, 16(18), :pii=19862, 2011. 
41. Vesenjak-Zmijanac J., Bedjanič M., Rus S., Kmet J. Virus meningoencephalitis in Slovenia: 3. Isolation of the causative agent. Bulletin of the World Health Organization, 12(4), 513-520, 1955.

42. Vilibic-Cavlek T., Kaic B., Barbic L. et al.: First evidence of simultaneous occurrence of West Nile virus and Usutu virus neuroinvasive disease in humans in Croatia during the 2013 outbreak. Infection, 42, 4, 689-95, 2014.

43. Vilibić-Čavlek T., Barbić Lj., Stevanović V., Mlinarić-Galinović G. Usutski virus: novi Flasvivirus u Hrvatskoj. Liječnički Vjesnik, 137, 46-51, 2015.

44. Weissenböck H., Kolodziejek J., Url A., Lussy H., Rebel-Bauder B., Nowotny N. Emergence of Usutu virus, an African mosquito borne flavivirus of the Japanese encephalitis virus group, central Europe. Emerging Infectious Diseases, 8, 652-656, 2002.

45. Weissenböck H., Hubálek Z., Bakonyi T., Nowotny N. Zoonotic mosquito-borne flaviviruses: worldwide presence of agents with proven pathogenicity and potential candidates of future emerging diseases. Veterinary Microbiology, 140, 271-280, 2010.

46. Weissenböck H., Bakonyi T., Rossi G., Mani P., Nowotny N. Usutu virus, Italy, 1996. Emerging Infectious Diseases, 19, 274-277, 2013.

47. Williams M.C., Simpson D.I., Haddow A.J., Knight E.M. The isolation of West Nile Virus from man and of Usutu virus from the bird-biting mosquito Mansonia aurites (Theobald) in the Entebbe area of Uganda. Annals of Tropical Medicine and Parasitology, 58, 367-374, 1964.

48. Wodak E., Richter S., Bagó Z., Revilla-Fernández S., Weissenböck H., Nowotny N., Winter P. Detection and molecular analysis of West Nile virus infections in birds of prey in the eastern part of Austria in 2008 and 2009. Veterinary Microbiology, 149, 3-4, 358-366, 2011.

49. Živojinović M., Stokić Nikolić S., Dobrosavljević I., Lazić M., Radojičić S., Stojanović M., Veljović Lj., Milićević V. Krpeljski encefalitis u Srbiji. Zbornik radova i kratkih sadržaja, 28. Savetovanje veterinara Srbije, Zlatibor 07-10. septembar 2017.godine, 109-113, 2017.

Primljeno: 06.12.2018.

Odobreno: 26.12.2018. 